\title{
REFINING THE SARLIÈVE PALEOLAKE (FRANCE) NEOLITHIC CHRONOLOGY BY COMBINING SEVERAL RADIOCARBON APPROACHES
}

\author{
Christine Hatté1,2 • Jean-Gabriel Bréhéret ${ }^{3}$ - Jérémy Jacob ${ }^{4}$ Jacqueline Argant ${ }^{5}$ • \\ Jean-Jacques Macaire ${ }^{3}$
}

\begin{abstract}
Dating sedimentary series spanning the past few tens of thousands of years is often problematic due to the quality of radiocarbon data obtained from organic matter (OM), including bulk OM. This problem recently arose when establishing the chronology of a sediment infill at the Sarliève paleolake (French Massif Central). In the studied section of the cores that covers the Neolithic, Ruppia seeds yielded consistent ages for the lower part (7195 \pm 75 to $6050 \pm 60 \mathrm{yr}$ BP). A reservoir age of $82 \pm 42{ }^{14} \mathrm{C}$ yr was estimated through the comparison of ages derived from charcoal, Ruppia seeds, and charophyte oogonia sampled on a single level. The upper part of the cores lacks macrofossils and bulk OM dating yields unusable data because of a significant contribution of aged OM derived from the Oligocene substratum in the catchment. We therefore performed dating of lipids extracted from the sediments. The age of the lipids was $2880 \pm 30 \mathrm{yr}$ BP near the top of the section, i.e. much younger than the age estimated from previous correlations based on pollen assemblages. These new data call into question previous paleoenvironmental interpretations. The combined dating methodology used for the Neolithic series of Sarliève is a rather uncommon approach that may help to refine chronologies of Holocene sedimentary series.
\end{abstract}

\section{INTRODUCTION}

Accurate radiocarbon chronologies of lake sedimentary archives are necessary for unraveling the timing of environmental changes estimated from various proxies. Organic matter (OM) is generally used in this respect in preference to carbonates that result exclusively from aqueous biogenic activity. There may be a significant discrepancy between the ${ }^{14} \mathrm{C}$ of carbonates and atmospheric ${ }^{14} \mathrm{C}$ activity at the time of deposition due to the unconstrained hardwater effect. While terrestrial plant macroremains can be used for this purpose, they are usually infrequent or even absent in lake sediment cores (Yansa and Long 2007). Another common approach is to use bulk sediment containing dispersed OM. Lake sedimentary OM, however, can originate from multiple sources. Allochtonous OM from the catchment derives either directly from vascular plants, from the erosion of soil OM, or from fossil OM eroded from the geological substratum. OM can also be produced in the water column from algae or aquatic macrophytes (either sessile or floating). All of these carbon sources could have different ${ }^{14} \mathrm{C}$ activities: (i) the contemporaneous atmosphere ${ }^{14} \mathrm{C}$ activity for vascular plants; (ii) depleted ${ }^{14} \mathrm{C}$ activity due to the lake "hardwater effect," for aquatic and semi-aquatic plants; (iii) slightly depleted ${ }^{14} \mathrm{C}$ activity due to a partial hardwater effect, for floating plants that use a mixture of atmospheric $\mathrm{CO}_{2}$ and $\mathrm{CO}_{2}$ evaded from the lake degassing for photosynthesis; and (iv) highly depleted ${ }^{14} \mathrm{C}$ activity for geological and eroded OM (MacDonald et al. 1991; Fontana 2005; Hatté and Jull 2007). A mixture of some or all these carbon sources can introduce a ${ }^{14} \mathrm{C}$ offset from the actual time of carbon deposition in the sediment, and hence result in potentially spurious ages.

The previously described problems in obtaining suitable material for ${ }^{14} \mathrm{C}$ dating arose during the study of a sedimentary core spanning the Neolithic extracted from the Sarliève paleolake, located in

\footnotetext{
${ }^{1}$ Laboratoire des Sciences du Climat et de l’Environnement, UMR CEA-CNRS-UVSQ 8212, Domaine du CNRS, bâtiment 12, 91198 Gif-sur-Yvette Cedex, France.

${ }^{2}$ Corresponding author. Email: Christine.Hatte@lsce.ipsl.fr.

${ }^{3}$ Université François-Rabelais de Tours, Laboratoire des GéoHydrosystèmes Continentaux, E.A 6293 GéHCo, Faculté des Sciences et Techniques, Parc Grandmont, 37200 Tours, France.

${ }^{4}$ Institut des Sciences de la Terre d’Orléans, Université d’Orléans, ISTO, UMR 7327, 45071, Orléans, France; CNRS/INSU, ISTO, UMR 7327, 45071 Orléans, France; BRGM, ISTO, UMR 7327, BP 36009, 45060 Orléans, France.

${ }^{5}$ LAMPEA-UMR 7269-CNRS, MMSH, 13094 Aix-en-Provence Cedex 2, France.
}

(C) 2013 by the Arizona Board of Regents on behalf of the University of Arizona

Proceedings of the 21st International Radiocarbon Conference edited by A J T Jull \& C Hatté

RADIOCARBON, Vol 55, Nr 2-3, 2013, p 979-992 


\section{Hatté et al.}

the Limagne rift of the French Massif Central (Bréhéret et al. 2003; Fourmont 2005; Trément et al. 2007; Fourmont et al. 2009). The challenge therefore was to chronologically constrain the evolution of the Neolithic population in the catchment for which abundant archaeological data are available (Trément et al. 2007; Macaire et al. 2010). These previous studies used terrestrial macrophyte remains, bulk organic matter, and wigeongrass (Ruppia) seeds.

Lipids extracted from the Sarliève lake sediments, in the SARL 17b core, are mainly higher plants in origin, indicated by the predominance of long-chain $n$-alkyl lipids ( $n$-alkanes, $n$-alkanols, and fatty acids), with minor macrophyte and cyanobacterial contributions (Disnar et al. 2011). Additionally, the predominance of $n$-alkanols over $n$-alkanes was interpreted as excellent preservation of higher plant remains that resulted from their short residence time in soils, accompanied by rapid transport to the lake via runoff or aerial transport and limited postdepositional decomposition. The lipid fraction extracted from the Sarliève lake sediments can therefore be considered a suitable ${ }^{14} \mathrm{C}$ target for refining the age model and providing a robust chronological framework for the Neolithic period in the newly investigated Sarliève lake core.

\section{MATERIALS}

\section{Study Site and Lacustrine Deposits}

The Sarliève paleolake is located $5 \mathrm{~km}$ SSE of Clermont-Ferrand (France) in the Limagne rift. Its catchment area has a total surface area of $29 \mathrm{~km}^{2}$ and is mainly composed of Oligocene to Miocene marl and limestone covered with soil (Figure 1). Previous studies on sedimentary archives showed that this lake records environmental changes from 13,500 BP until the 18th century, when it was drained (Fournier 1996). A detailed evolution of the environment when Neolithic settlements were established at the lake was reconstructed from a study of stratigraphic levels corresponding to the Neolithic period (Trément et al. 2007; Fourmont et al. 2009; Macaire et al. 2010). This corresponds more or less to the Atlantic chronozone, i.e. 8000-5000 yr BP (de Beaulieu et al. 1988; Fourmont 2005). The sediments deposited during this time are composed of fine-grained silty marls, greenish gray to brown, mainly calcitic, that display numerous laminated layers rich in pristine Ca-dolomite, with small amounts of aragonite, which are clearly autochthonous (Bréhéret et al. 2003). These layers correspond to the fossilization of microbial mats developed at the bottom of a saline pan environment (Bréhéret et al. 2008; Disnar et al. 2011) as a consequence of excess evaporation from the restricted system. The homogeneous, physically mixed, and bioturbated intervals that separate these laminated layers result from more humid episodes that could have induced the opening of the system. The maximum depth reached by the lake was about $6 \mathrm{~m}$, therefore implying large fluctuations in lake level during the interval studied. The sedimentation rate is not regular because of climate changes (alternation of wet and dry phases) and anthropogenic impact (Macaire et al. 2010) leading to catchment erosion. However, for events of short duration ( $<100 \mathrm{yr}$ ), the impact of erosion on sediment accumulation is difficult to assess given the precision of dating.

The investigated section is overlain by $2 \mathrm{~m}$ of lacustrine sediments composed of greenish gray to brown silty marls that are covered by a gray clayish soil belonging to the so-called terres noires of the Limagne rift. This soil, which is heavily waterlogged most of the year, is currently used for cereal cultivation. The catchment is covered by a variety of soils derived from the weathering of different geological formations (Oligocene-Miocene marls and limestones, Miocene basalts, and Holocene alluvia): rendzines, calcic brown soils, and clayey calcareous black soils (Bornand et al. 1968).

Currently, crops and especially cereals dominate the catchment. Non-cultivated areas are found above $450 \mathrm{~m}$ on the slopes of the Gergovie Plateau, whereas urban zones dominate the low-lying 
areas around the lake (Figure 1). Human settlements have been in the catchment since the Neolithic, with different episodes (Trément et al. 2007; Fourmont et al. 2009). The anthropogenic impact affected the entire lake area due to erosion, bringing organic matter of various origins and modifying the hydrology (Fourmont 2005; Fourmont et al. 2009; Macaire et al. 2010).

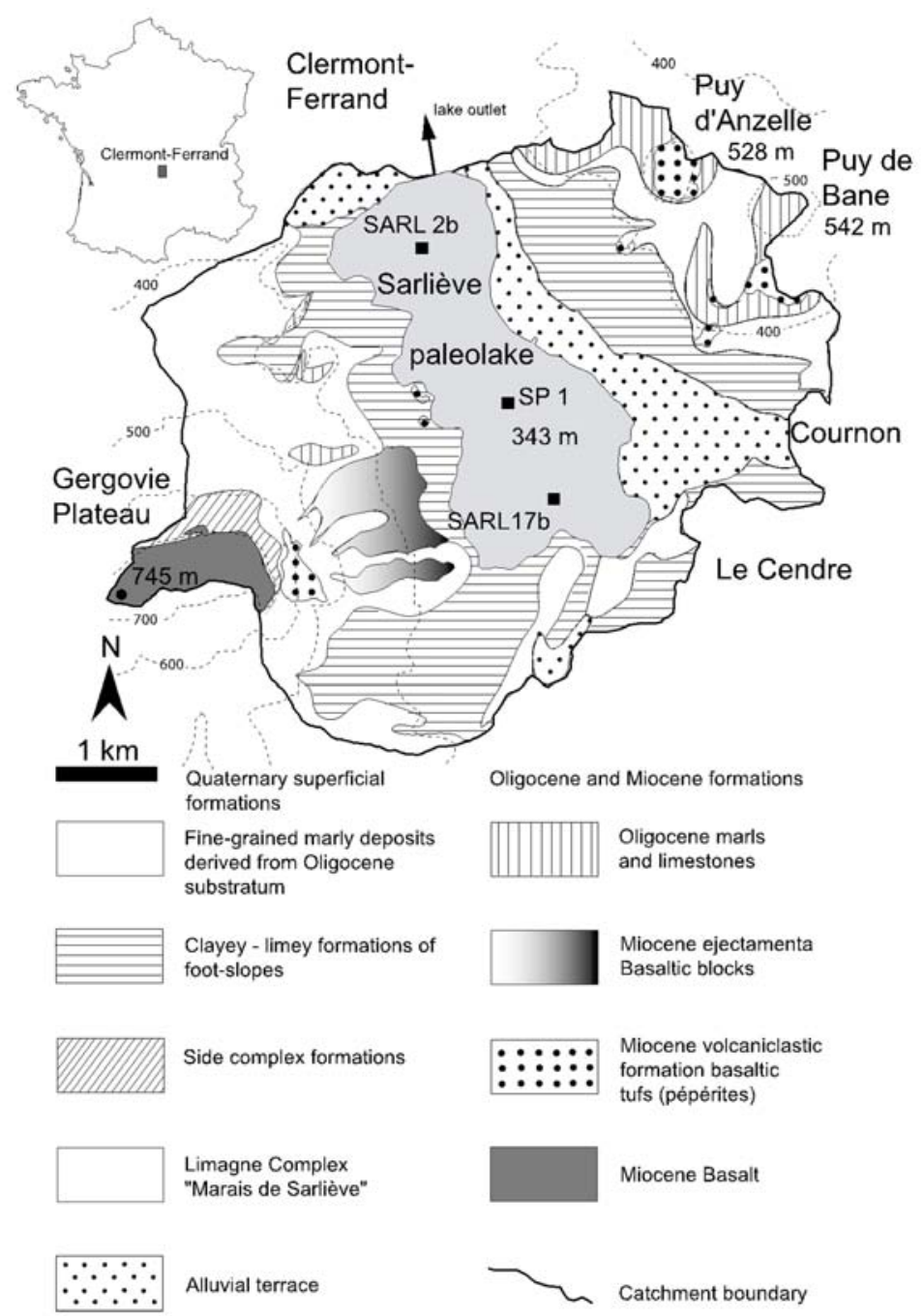

Figure 1 The Sarliève paleolake in its catchment area (Limagne rift, French Massif Central), from the geological map 1/50,000, no. XXV-31 Clermont-Ferrand (Aubert et al. 1973).

\section{Sampling}

Core SARL.17b (Figure 1) was extracted between 2.00 and $3.87 \mathrm{~m}$ depth below the present-day soil surface (Figure 2), using a percussion corer (Eijelkamp FB 60; Atlas Copco Berema AB, Stockholm, Sweden). For dating purposes, 15 samples of Ruppia seeds found in the lower part (2.93$3.68 \mathrm{~m}$ ) of the section were collected and placed in plastic boxes. They have the advantage of being deposited and preserved in situ in laminated layers, without reworking. Since seeds, as well as other 


\section{Hatté et al.}

macroremains, were lacking in the upper part (2.00-2.92 m), 4 bulk samples (10 mm thick) were also sampled and placed in plastic bags. Two additional samples (of the same thickness) were also collected in the upper part of the section from organic-rich layers and packaged in aluminum foil, in order to analyze lipid fractions.

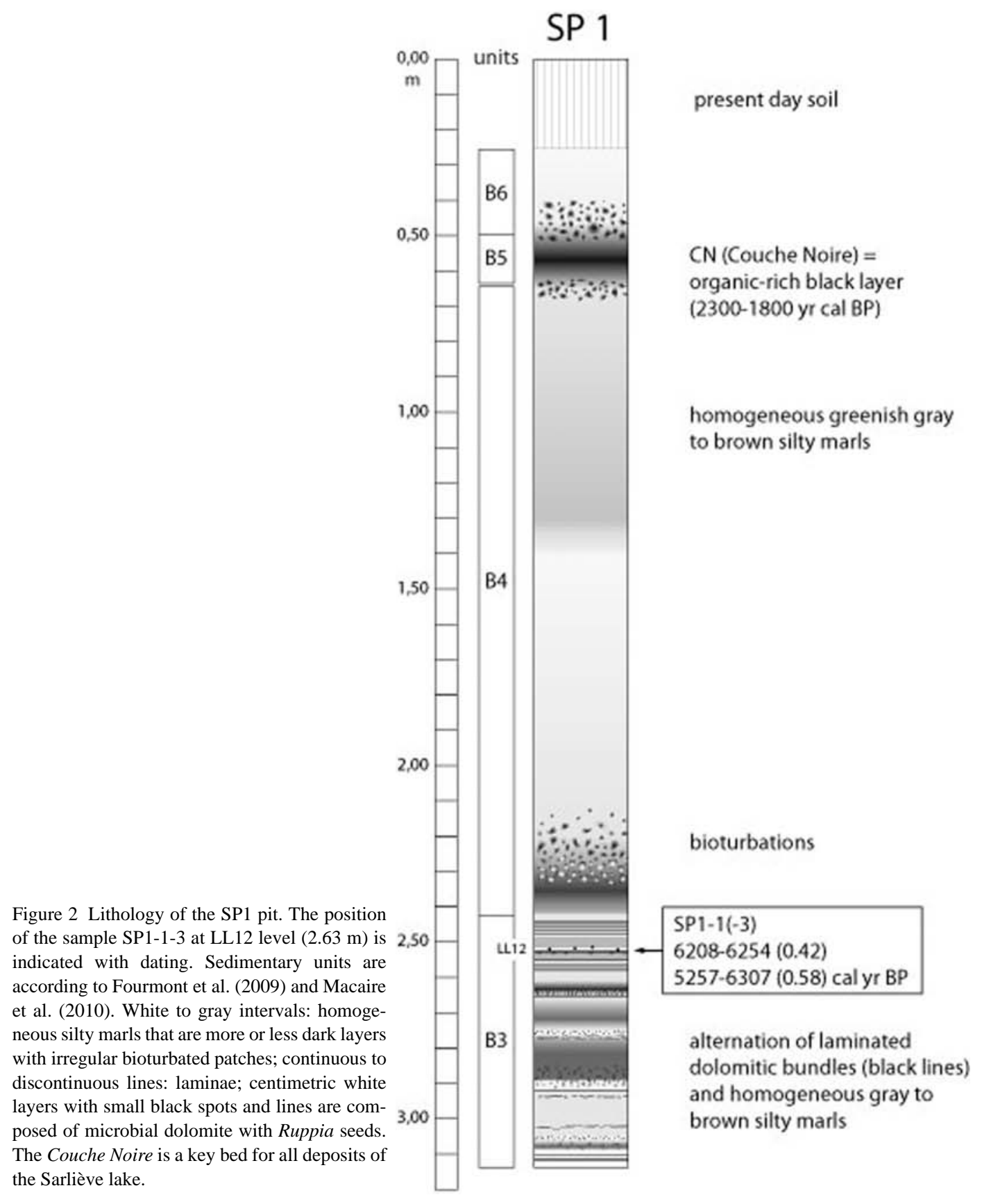




\section{Refining the Sarliève Paleolake Neolithic Chronology}

To clarify the dating of the sediments studied and evaluate the reservoir age effect, further sampling was performed on a laminated horizon observed from a pit (SP 1) dug in the same context 1350 m north of SARL.17b (Figures 1 and 2). The sample taken at $2.6 \mathrm{~m}$ depth in this pit can be correlated according to lithostratigraphy with the LL12 level at $\sim 2.70 \mathrm{~m}$ in SARL.17b. Charcoal, charophyte oogonia (organic membranes of Chara braunii and Chara cf. canescens; cf. Bréhéret et al. 2003), and Ruppia seeds were recovered from the same layer in the SP1 pit, thus offering the opportunity to compare ${ }^{14} \mathrm{C}$ ages from carbon of different origins.

\section{Main Characteristics of Macroremains}

Wigeongrass (Ruppia) is a shallow hydrophyte phanerogame (0-4.5 $\mathrm{m}$ depth according to Kantrud 1991; see also Verhoeven 1979) adapted to brackish to saline waters. Ruppia maritima has the widest known salinity tolerance of any submerged angiosperm (Kantrud 1991; Murphy et al. 2003) and extracts photosynthetic carbon from dissolved inorganic carbon (DIC) (e.g. Beer et al. 2006).

Charophytes are shallow freshwater algae fixed to the substrate by rhizoids (Soulié-Märsche 2002). They are characterized by female fructifications, oosporanges, usually mineralized in carbonate: the gyrogonites, a kind of shell that encapsulates the organic oospore. Several species are adapted to brackish to saline waters as is the case for Chara cf. canescens Loiseleur and, to a lesser extent, Chara braunii Gmelin. Ch. canescens is adapted to very shallow environments (down to several decimeters), whereas Ch. braunii is found between 3 and $5 \mathrm{~m}$ depth (Hutchinson 1975). In addition to photosynthesis using $\mathrm{CO}_{2}$, charophytes assimilate bicarbonate ions (Smith 1968; Raven 1970; Hutchinson 1975).

$\mathrm{HCO}_{3}{ }^{-}$is abundant, particularly in alkaline environments (Steeman Nielsen 1947; Madsen and Sand-Jensen 1991) and is not a limiting factor in the Sarliève lake. This DIC comes from 3 potential sources: (1) atmospheric $\mathrm{CO}_{2}$ diffusion across the lake surface; (2) soil gas $\mathrm{CO}_{2}$ (root respiration and the decay of organic material release $\mathrm{CO}_{2}$ ) from the catchment; and (3) old carbon from OligoceneMiocene carbonates in the catchment subsurface. The first source involves an almost instantaneous equilibrium with atmospheric ${ }^{14} \mathrm{C}$. The second introduces a delay depending on the proportion and of the age (older from some decades to some centuries than contemporaneous atmosphere) of the source organic matter, but the third could introduce significant biases due to the dilution of the DIC by the ${ }^{14} \mathrm{C}$-dead carbon that comes from the dissolution of ancient carbonates.

\section{METHODS}

A combination of ${ }^{14} \mathrm{C}$ approaches was used for this study. Several types of ${ }^{14} \mathrm{C}$ analyses were investigated here: bulk organic matter, macroremains (Ruppia seeds, charophyte oospores, charcoal), deasphalted lipids, and asphaltenes extracted from bulk sediments.

\section{Bulk Organic Matter and Macroremains}

Bulk organic matter, charcoals, Ruppia seeds, and charophyte oospores underwent the classical acid-alkali-acid (AAA) treatment $\left(\mathrm{HCl} 0.5 \mathrm{~N}\right.$ at $80{ }^{\circ} \mathrm{C}$ for $1 \mathrm{hr}, \mathrm{NaOH} 0.1 \mathrm{~N}$ at $80{ }^{\circ} \mathrm{C}$ for $1 \mathrm{hr}, \mathrm{HCl}$ $0.5 \mathrm{~N}$ for $1 \mathrm{hr}$ at $80^{\circ} \mathrm{C}$ ) and rinsed with ultrapure water after each step. The residue was then dried in an oven under vacuum at $40^{\circ} \mathrm{C}$. Some $100 \mathrm{mg}$ of dried sample (evaluated to provide $\sim 1 \mathrm{mg} \mathrm{C}$ ) was introduced in a precombusted quartz tube with $500 \mathrm{mg}$ of $\mathrm{CuO}$, heated at $850^{\circ} \mathrm{C}$ under vacuum just prior the use, and $1 \mathrm{~cm}$ of silver wire. The tube was evacuated and flame-sealed. It was then placed in a furnace at $900{ }^{\circ} \mathrm{C}$ for $6 \mathrm{hr}$ and cracked under vacuum. The evolved $\mathrm{CO}_{2}$ was passed through a $-80^{\circ} \mathrm{C}$ dry-ice trap to remove $\mathrm{H}_{2} \mathrm{O}$, cryogenically isolated, the amount of $\mathrm{CO}_{2}$ measured, and then flame-sealed into the quartz tube. 


\section{Hatté et al.}

\section{Lipid Extraction and Preparation for ${ }^{14} \mathrm{C}$ Dating}

Some $49 \mathrm{~g}$ (SARL.17b/48bis) and $21 \mathrm{~g}$ (SARL.17b/44) of dried (50 ${ }^{\circ} \mathrm{C}$ overnight in an oven) and crushed sediment were ultrasonically extracted with $250 \mathrm{~mL}$ of a mixture of dichloromethane-methanol (DCM:MeOH 9:1). The operation was repeated in order to maximize lipid extraction. After filtration, the extracts were combined and evaporated under vacuum. Precipitation of asphaltenes was achieved by diluting the total extract in few drops of DCM and then adding cold heptane in excess. After centrifugation, the supernatant was collected and evaporated under vacuum. Asphaltenes and deasphalted lipids were recovered with DCM, collected in precombusted $\left(450^{\circ} \mathrm{C}\right.$ overnight) Pyrex ${ }^{\circledR}$ tubes, and DCM was evaporated under nitrogen. The deasphalted lipid extract was diluted in $2.5 \mathrm{~mL}$ and introduced into glass tubes and the solvent was removed under a stream of nitrogen. The deasphalted lipids and the asphaltenes of samples SARL.17b/48bis and SARL.17b/44 were converted to $\mathrm{CO}_{2}$ by flame combustion under pure $\mathrm{O}_{2}$ atmosphere (about $-500 \mathrm{~mm} \mathrm{Hg}$ ) in a pre-evacuated $\left(10^{-6}\right.$ Torr) vacuum line devoted to small samples (typically $<500 \mu \mathrm{g}$ of $\mathrm{C}$ ). The evolved gas was passed through water and $\mathrm{Cu}$ traps to remove $\mathrm{H}_{2} \mathrm{O}, \mathrm{O}_{2}$, nitrogen, and sulfur oxides, and was then quantified. Pure $\mathrm{CO}_{2}$ was flame-sealed in a Pyrex tube until graphitization and ${ }^{14} \mathrm{C}$ measurements at the LMC14 laboratory, as described above. Pure $\mathrm{O}_{2}$ was chosen instead of $\mathrm{CuO}$ as oxygen source in order to minimize potential contamination by modern carbon, e.g. adsorbed on $\mathrm{CuO}$. Some grayish components remained on the combustion tube of the SARL.17b/44 asphaltene after combustion. These residues might correspond to the heaviest part of the asphaltene fraction or residues of incomplete combustion of asphaltene. Residues were then enclosed with $\mathrm{O}_{2}$ precombusted $\mathrm{CuO}$ under vacuum following the classical procedure for large AMS samples (see above).

\section{Graphitization and ${ }^{14} \mathrm{C}$ Measurement}

Evolved $\mathrm{CO}_{2}$ were graphitized by reduction with $\mathrm{H}_{2}$ on iron with a $\mathrm{Fe} / \mathrm{C}$ ratio of 3 (Arnold et al. 1987, 1989). The $\mathrm{Fe} / \mathrm{C}$ powder was pressed in a target holder and ${ }^{14} \mathrm{C}$ measured on ARTEMIS, the AMS of the LMC14 facility (Cottereau et al. 2007). ${ }^{14} \mathrm{C}$ activity is calculated by comparison with standard prepared from oxalic acid HOx I and normalized to $\delta^{13} \mathrm{C} .{ }^{14} \mathrm{C}$ ages are calculated according to the Mook and van der Plicht (1999) recommendations. The resulting ${ }^{14} \mathrm{C}$ activity is corrected from background ${ }^{14} \mathrm{C}$ evaluated on both a ${ }^{14} \mathrm{C}$-free carbonate ("C1") thermically decomposed into $\mathrm{CO}_{2}$ to assert the line itself and on a ${ }^{14} \mathrm{C}$-free charcoal ("Afrique du Sud" extracted from the Paleolithic level of Border Cave, South Africa, and dated to $>70 \mathrm{kyr}$ ) that underwent the same chemical protocol as the bulk OM and seeds. Mass dependent background correction was applied to all samples. We used the same background correction for lipid fractions as we do not have any ${ }^{14} \mathrm{C}$-free and known-age standards for this type of material. As recorded on the LMC14 result sheet, final ${ }^{14} \mathrm{C}$ uncertainties result from statistical error, results variability, and background subtraction.

\section{RESULTS AND DISCUSSION}

\section{Bulk Organic Matter}

${ }^{14} \mathrm{C}$ dates derived from bulk OM yielded ages of 6000-6700 yr BP, irrespective of depth (Table 1), and show clear chronological inversions (Figure 3 ). This can probably be attributed to the contribution of exogenous carbon, since pollen analysis shows a significant proportion of pollen grains from the weathering of Oligocene-Miocene rocks in the catchment (Argant and Lopez-Saez 2004; Trément et al. 2007). Therefore, a massive input of carbon derived from the catchment into the lake, including the surrounding soil erosion, which can be suspected, would induce an aging effect. 
Refining the Sarliève Paleolake Neolithic Chronology

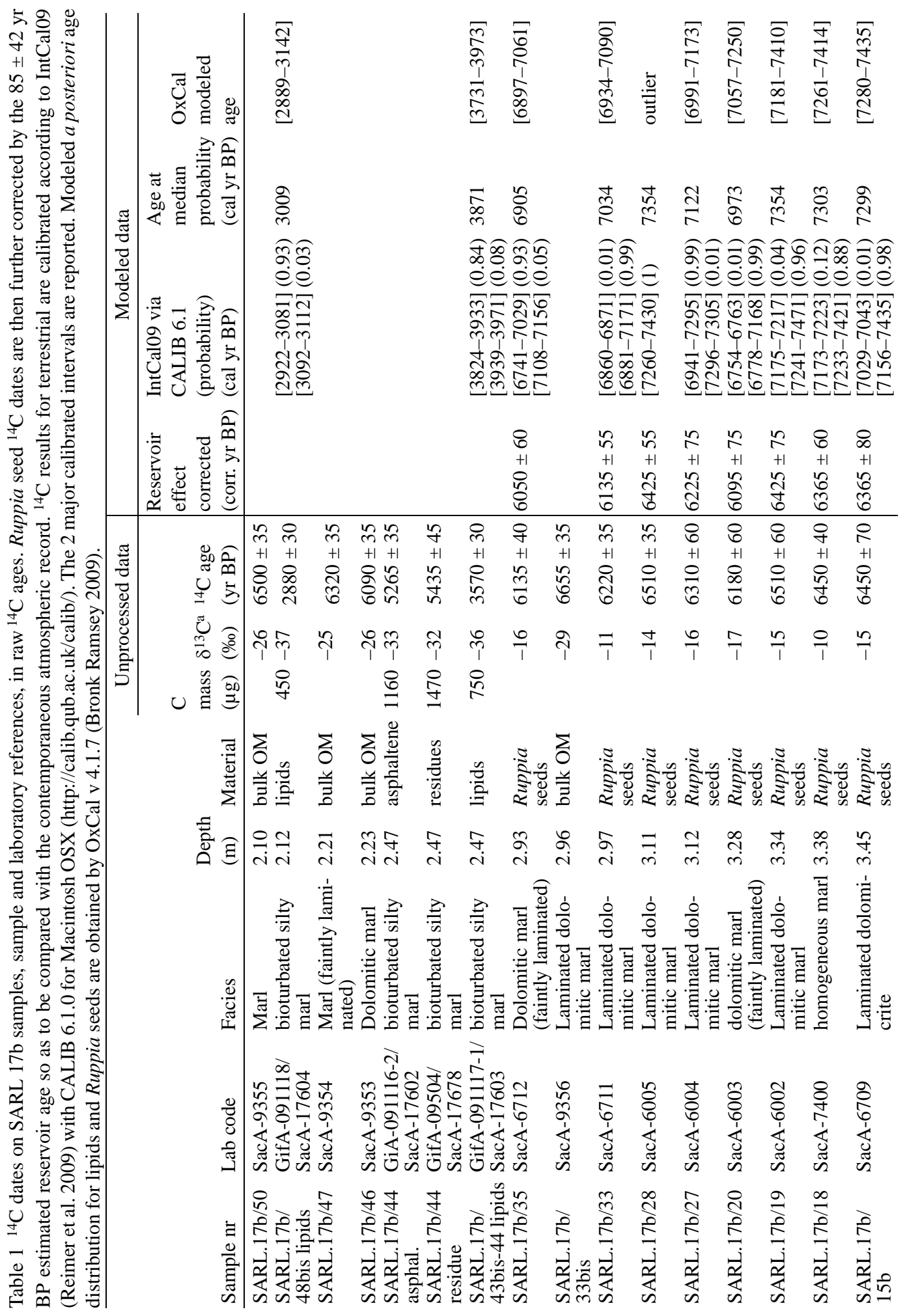




\section{Hatté et al.}

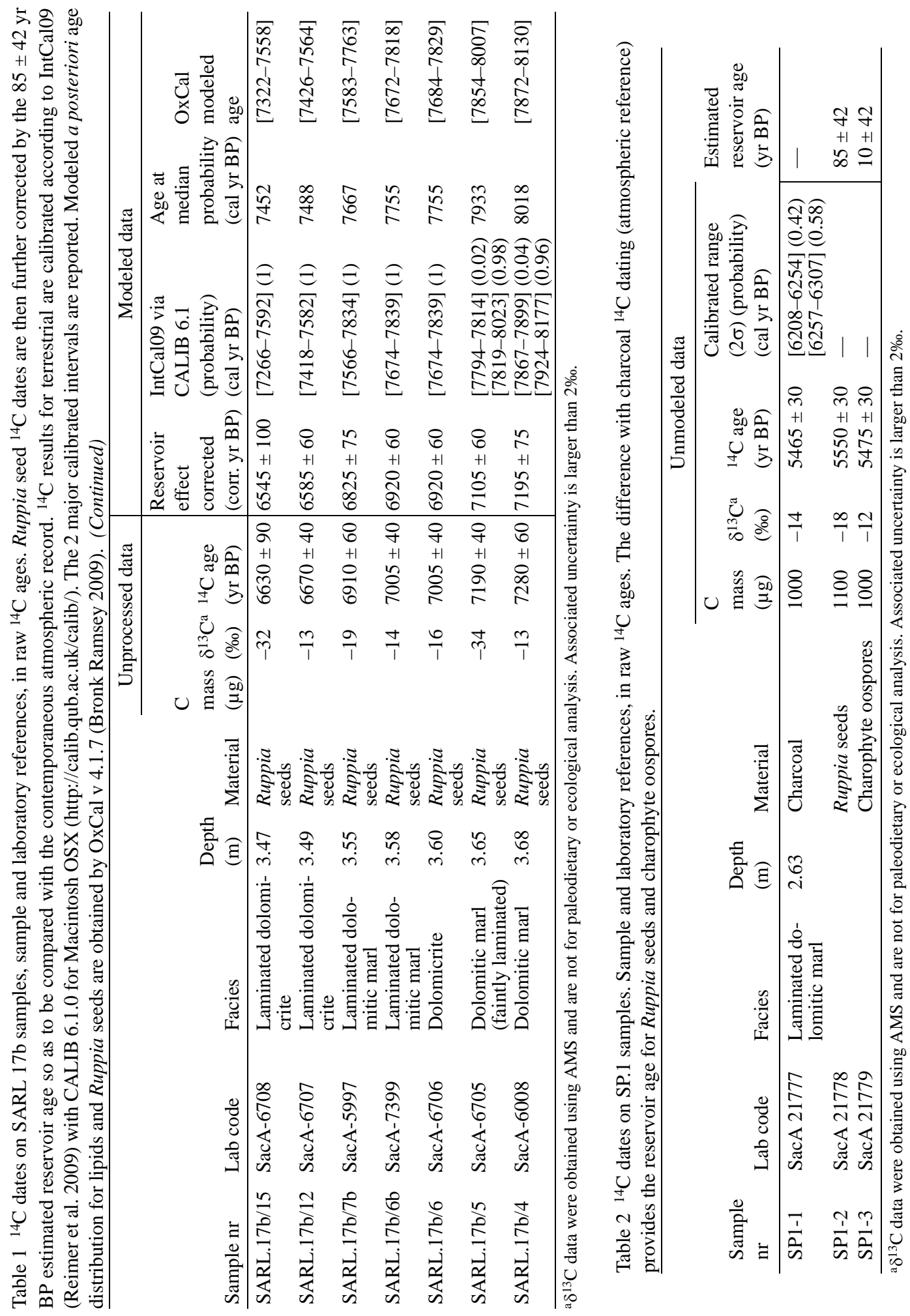




\section{Refining the Sarliève Paleolake Neolithic Chronology}
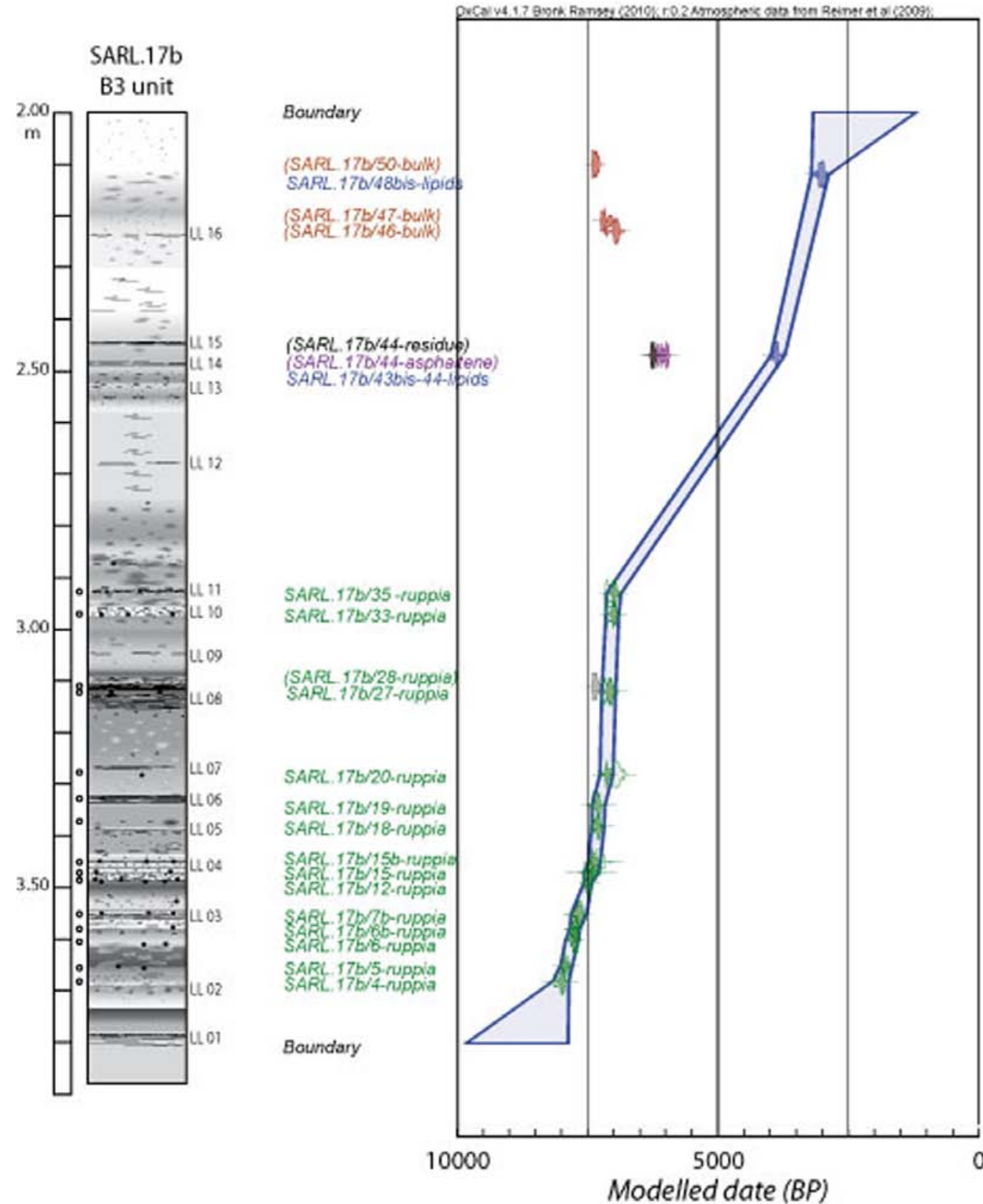

Figure 3 Age-depth relationships for core SARL.17b. Depth is shown in meters below present-day soil surface and the $x$ axis is in OxCal modeled yr BP (see text). Lithology as for Figure 2. Laminae are listed as LL 01 to LL 16; centimetric white layers with small black spots and lines are composed of microbial dolomite with Ruppia seeds. Light circles: sampled Ruppia seeds. Modeled age: prior (light) and a posteriori (dark) age probability distribution for ${ }^{14} \mathrm{C}$ dates are shown for Ruppia seeds (reservoir age corrected, green), bulk organic matter (brown), lipids (blue), asphaltene (purple), and residue (black). The outlier SARL.17b/28 Ruppia ${ }^{14} \mathrm{C}$ age is shown in gray. The sample name in parentheses is for a sample whose ${ }^{14} \mathrm{C}$ age is excluded in the age-depth model. The OxCal model is shown in the blue-shaded zone. Two boundaries are fixed at the core top and bottom to close the model but do not impact the model definition. 


\section{Hatté et al.}

\section{Macroremains}

Macroscopic observation and lithostratigraphy (laminated sediments) indicate that seeds of wigeongrass (Ruppia) are not reworked. The geochronological succession is consistent and only 1 slight inversion is observed (SARL.17b/28). However, as already stated, Ruppia uses DIC as a source of photosynthetic carbon. Aging as a result of the hardwater effect is therefore very likely. This effect was assessed by using a combination of terrestrial and aquatic ${ }^{14} \mathrm{C}$ dating in the lateral pit SP1 (Figure 2) and the results were then applied on the raw ${ }^{14} \mathrm{C}$ dates.

The dates obtained on the 3 macroremains from the same sample from pit SP 1 are given in Table 2 and are as follows: charcoal: $5465 \pm 30$ yr BP; Ruppia seeds: $5550 \pm 30$ yr BP; charophyte oogonia: $5475 \pm 30 \mathrm{yr}$ BP. The charcoal age differs from that of wigeongrass by only $\sim 85 \mathrm{yr}$. This value ( $85 \pm$ $42 \mathrm{yr}$ BP) may be used to correct the reservoir effect of the dates obtained on Ruppia seeds. As an approximation, it is assumed relatively constant over time corresponding to the accumulation of sediments of the core, although it may have changed slightly over time (Geyh et al. 1998, 1999). The relative similarity between the datings of charcoal and charophyte oogonia should be emphasized. Charophytes, which use both atmospheric and DIC carbon as a source of photosynthetic carbon, show consistently less ${ }^{14} \mathrm{C}$ offset. This further indicates that the reservoir effect plays a negligible role in the ${ }^{14} \mathrm{C}$ composition of charophyte fructifications and therefore that charophyte oogonia ( $C$. cf. canescens) can be used can be used in ${ }^{14} \mathrm{C}$ dating. It should be noted that as the lake has been dry for the last 2 centuries, dating was not possible on the present-day DIC nor on aquatic plants.

\section{Lipids}

For the ages obtained on lipid extracts (Table 1, Figure 3), the sample SARL.17b/44 (2.47 m) provides an age of $3570 \pm 30 \mathrm{yr}$ BP for the deasphalted lipid fraction, whereas the asphaltene fraction gives $5265 \pm 35 \mathrm{yr}$ BP and the residue fraction gives $5435 \pm 45 \mathrm{yr}$ BP. The lipid fraction of the sample SARL.17b/48b at $2.12 \mathrm{~m}$ provides an age of $2880 \pm 30 \mathrm{yr}$ BP. Thus, the deasphalted lipid fraction shows significantly younger ages than those measured either on bulk OM or on asphaltenes and residues. These ages are nevertheless coherent, with lipids extracted from sample SARL.17b/48b being younger than those extracted from sample SARL.17b/44.

The difference in ${ }^{14} \mathrm{C}$ dates between the asphaltene (and residue) and the deasphalted lipid fraction ( $\sim 1700$ to $2000{ }^{14} \mathrm{C}$ yr) implies that organic compounds that differ in origin and in age comprise these fractions. The age difference between deasphalted lipids and asphaltenes in sample SARL.17/ 44 is $\sim 2000{ }^{14} \mathrm{C}$ yr (Table 1), i.e. slightly less than the difference between the age of the lipid fraction in sample SARL.17b/48bis and that of bulk OM of the 2 closest samples (SARL.17b/47 and SARL.17b/50), which is $\sim 2500{ }^{14} \mathrm{C}$ yr. The aging of the asphaltene and residue fractions may be attributed to the contribution of old carbon derived either from soils or from the geological substratum. Thus, and although there is no current knowledge/evidence for the aging of asphaltenes when compared to deasphalted lipids, our results suggest that removing asphaltenes from a lipid extract makes it possible to access a significantly younger carbon fraction than that of the total lipid extract and of the bulk OM. ${ }^{14} \mathrm{C}$ dating performed on individual molecules of which the source organism is constrained remains, when feasible, the most efficient means of avoiding using fossil organic matter (i.e. Eglinton et al. 1997).

\section{Age Model}

Macroremains of terrestrial plants remain the most reliable material to establish a ${ }^{14} \mathrm{C}$ chronology of a lacustrine or palustrine record (Hatté and Jull 2007). However, if they are not available, alternative 


\section{Refining the Sarliève Paleolake Neolithic Chronology}

materials should be sought. Macroremains from aquatic or floating plants can be used with relative confidence if there is no geologically old carbonate in the lake catchment or the reservoir age can be established. In the latter case, reservoir age has also to reasonably be assumed not to have significantly changed over the time of sequence deposition. Climatic and geomorphological variations have to be taken into consideration. The use of bulk OM should remain the least preferred option since it contains carbon of undetermined sources and ages. This is the problem we faced for the upper part of the sequence studied here. In the absence of any reliable macroremains, the analysis of the lipid fraction mostly composed of molecular biomarkers of vascular higher plants appears an efficient alternative. The Sarliève chronology was thus completed by using ${ }^{14} \mathrm{C}$ results obtained on these lipid fractions.

The age-depth model is built on ${ }^{14} \mathrm{C}$ dating of Ruppia seeds and lipids using the OxCal program, designed for the analysis of chronological information (Bronk Ramsey 2008, 2009) based on (1) calibrated intervals obtained by IntCal09 calibration (Reimer et al. 2009) on reservoir-age-corrected Ruppia and on lipid ${ }^{14} \mathrm{C}$ datings; (2) stratigraphical information (i.e. succession order); and (3) Bayesian statistics. OxCal can be used to model the a posteriori modeled age distribution for all samples and to establish the most likely age-depth model. OxCal can also be used to identify likely outliers within a dating series. This is the case for SARL.17b/28 sample in the Sarliève series, which appears too old and falls outside all possible age-depth models $(\mathrm{A}=0.9$ for this point in the P_Sequence context). When this datum is removed, OxCal provides the a posteriori age distribution (Table 1) and age-depth model presented in Figure 3 (chosen option: P_Sequence that returns $A_{\text {model }}=105.3$ and $A_{\text {overall }}=105.8$ ).

The coherency of the age model applying the reservoir age we defined on only 1 couple of dates corroborates our assumption of constant reservoir age along the sequence. The model clearly shows a constant rapid accumulation from 3.7 to $2.9 \mathrm{~m}$ with accumulation of $80 \mathrm{~cm}$ in $1100 \mathrm{yr}$, followed by a drastic slowdown or a hiatus leading to a missing part until $2.5 \mathrm{~m}$, and then a rapid accumulation rate from 2.5 to $2.1 \mathrm{~m}$, with $40 \mathrm{~cm}$ in $~ 860 \mathrm{yr}$.

\section{Paleoenvironmental Implications}

The newly acquired age-depth model specifies the top of the Ruppia seed-rich laminites (close to $2.75 \mathrm{~m}$ on SARL.17b) as $6250 \mathrm{cal} \mathrm{BP}$, and the top of the laminite interval as about $3000 \mathrm{cal} \mathrm{BP}$ instead of 5300 estimated BP (Fourmont et al. 2009; Macaire et al. 2010). Considering that dates based on OM bulk were too old by at least 1000 yr, Fourmont et al. (2009) excluded these data and preferred to define their age model by correlation with the palynological framework.

Trément et al. (2007) estimated the Fagus diffusion observed in another Sarliève core, SARL 2b, as $6390 \pm 50$ yr BP (i.e. [7247-7426 yr cal BP]) based on bulk OM dating (Figure 4), but the authors considered this data as obviously too old compared to the data from the other sites in the French Massif Central, which were estimated as 5800-5400 yr BP. Correlations between SARL.17b and SARL.2b (Figure 4) enable this event to be placed at $2.50 \mathrm{~m}$ depth in SARL.17b, close to $4000 \mathrm{yr}$ cal BP according to the present age-depth model. The Atlantic-Subboreal chronozone transition, based on the Fagus proliferation, indicated as $5770 \pm 70$ yr BP (i.e. 6411-6727 yr cal BP) according to the same authors, also judged as too old by $\sim 1000 \mathrm{yr}$, is close to $3100 \mathrm{yr}$ BP ( 3300 cal BP, at $\sim 2.25 \mathrm{~m}$ taking correlations into account) according to the new model. This event also appears to be much more recent than the dates indicated for other sites in the French Eastern Massif Central near Sarliève, namely 4840 yr BP ( 5500 yr cal BP) (Argant and Cubizolle 2005). 


\section{Hatté et al.}

SARL $2 b$

SARL $17 b$

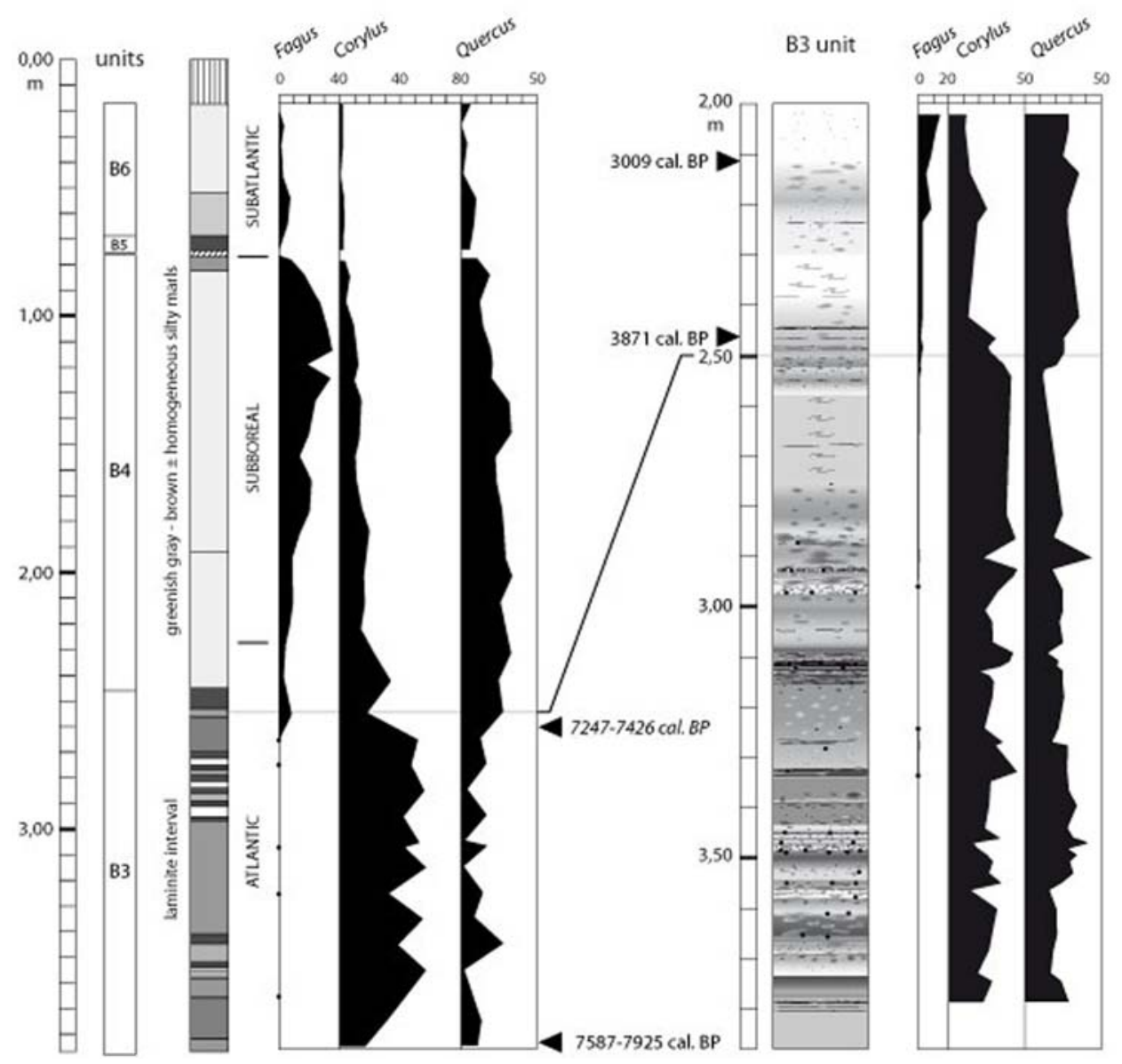

Figure 4 Correlations between SARL 17b and SARL 2b (Trément et al. 2007). Sedimentary units according to Fourmont et al. (2009) and Macaire et al. (2010). Distribution of Fagus, Corylus, and Quercus pollen. Age indicated for $3.84 \mathrm{~m}$ in SARL 2b was obtained on Ruppia seed (and so it must be corrected for the reservoir effect as estimated in the present work); however, the age for $2.60 \mathrm{~m}$ was obtained on bulk OM and must be dismissed. The diffusion of Fagus dated by Trément et al. (2007) in SARL 2b is synchronous with a decrease in Corylus and an increase in Quercus. A similar pattern is observed in SARL 17b, for which the dating is substantially more recent.

Three possible explanations for these differences can be suggested: (i) the type of material used to date these previous series; (ii) more probably, the obvious diachronism of the vegetation evolution depending on the altitude of the sites studied, and their climatic conditions — as noted by Trément et al. (2007), all the sites previously studied and used as reference for palynology are located between 975 and $1400 \mathrm{~m}$ asl whereas the altitude of the Sarliève basin is only $345 \mathrm{~m}$ asl, and this area is characterized today by much drier conditions than in the nearby massifs (Kessler and Chambraud 1986); and (iii) a potential differing impact of human activities between the different sites.

The change in sedimentation rate that occurs above $2.90 \mathrm{~m}$ in SARL.17b could be explained in 2 ways. First, the geometry of the lacustrine fill extends far laterally on the basin margin so that even an increase in sedimented volume, as calculated by Macaire et al. (2010), could in fact result in a smaller height of deposits and thus in a decrease in the vertical sedimentation rate. Second, the cli- 


\section{Refining the Sarliève Paleolake Neolithic Chronology}

matic evolution is characterized by an increase in moisture as indicated by palynology (Trément et al. 2007) and sedimentology (Bréhéret et al. 2008). This led to a rise in lake level and the opening of the lacustrine system by the outlet. As a result, the suspended matter was then exported, thus depriving the lake of this supply.

\section{CONCLUSION}

By combining several ${ }^{14} \mathrm{C}$ approaches - evaluating the freshwater reservoir effect, dating of macrofossils and lipids extracted from sediments (excluding asphaltenes that were shown to be aged) - the chronological framework of the Neolithic paleoenvironment around the Sarliève paleolake has been refined. This study provides the first reliable dates to characterize the end of the lake restriction, and the advent of the Fagus proliferation in the Sarliève area (3300 cal BP), which is much more recent than the beginning of the Subboreal chronozone known in the French Massif Central (5500 cal BP). The decrease in the sedimentation rate evidenced around $6250 \mathrm{cal} \mathrm{BP}$ is attributable to a rise in lake level and the concomitant export of suspended matter by opening of the outlet.

\section{ACKNOWLEDGMENTS}

We wish to thank the French National Facility for ${ }^{14} \mathrm{C}$ measurements (LMC14) for carefully conducting the chemical treatment of bulk sediment and macrofossils and performed all ${ }^{14} \mathrm{C}$ activity measurements. We would like to express our sincerest thanks to the 2 anonymous reviewers for their highly constructive comments and suggestions. This work was supported by grant n ${ }^{\circ} 05 \mathrm{CV} 054$ from the ECLIPSE (CNRS-INSU) project (2006-2007) and has benefited from the ARTEMIS Program. This is an LSCE contribution $n^{\circ} 4554$.

\section{REFERENCES}

Argant J, Cubizolle H. 2005. L’évolution holocène de la végétation des monts de la Madeleine, du Forez, du Livradois et du Pilat (Massif Central oriental, France). L'apport d'une nouvelle série d'analyses palynologiques. Quaternaire 16(2):119-42.

Argant J, Lopez-Saez JA. 2004. L’occupation humaine du bassin de Sarliève depuis le Néolithique d’après la palynologie et l'étude des microfossiles non polliniques., In: Actes des 5e Rencontres méridionales de Préhistoire récente Auvergne et Midi. Clermont-Ferrand, 8-9 November 2002. Préhistoire du Sud-Ouest, supplement 9. p 25-34.

Arnold M, Bard E, Maurice P, Duplessy JC. $1987 .{ }^{14} \mathrm{C}$ dating with the Gif-sur-Yvette Tandetron accelerator: status report. Nuclear Instruments and Methods in Physics Research B 29(1-2):635-45.

Arnold M, Bard E, Maurice P, Valladas H, Duplessy JC. 1989. ${ }^{14} \mathrm{C}$ dating with the Gif-sur-Yvette Tandetron accelerator: status report and study of isotopic fractionation in the sputter ion source. Radiocarbon 31(3): 284-91.

Aubert M, Bouiller R, Camus G, Cochet A, D’Arcy D, Giot D, Jeambrun M, Roche A, Bonhommet N. 1973. Clermont-Ferrand, Carte géologique de la France à 1/ 50 000, XXV-31. Orléans: Bureau de Recherches Géologiques et Minières, Service Géologique National. $64 \mathrm{p}$.
Beer S, Axelson L, Björk M. 2006. Modes of photosynthetic bicarbonate utilisation in seagasses, and their possible roles in adaptation to specific habitats. Biologia Marina Mediterranea 13:3-7.

Bornand M, Callot G, Favrot JC, Servat E. 1968. Les sols du Val d'Allier. Montpellier: INRA Service d'Etude des Sols. 220 p.

Bréhéret JG, Macaire JJ, Fleury A, Fourmont A, SouliéMärsche I. 2003. Indices de confinement dans les dépôts lacustres holocènes de Sarliève (Limagne, France). Comptes Rendus Geoscience 335:479-85.

Bréhéret JG, Fourmont A, Macaire JJ, Négrel P. 2008. Microbially mediated carbonates in the Holocene deposits from Sarliève, a small ancient lake of the French Massif Central, testify to the evolution of a restricted environment. Sedimentology 55(3):557-78.

Bronk Ramsey C. 2008. Deposition models for chronological records. Quaternary Science Reviews 27(1-2): 42-60.

Bronk Ramsey C. 2009. Bayesian analysis of radiocarbon dates. Radiocarbon 51(1):337-60.

Cottereau E, Arnold M, Moreau C, Baqué D, Bavay D, Caffy I, Comby C, Dumoulin J-P, Hain S, Perron M, Salomon J, Setti V. 2007. Artemis, the new ${ }^{14} \mathrm{C}$ AMS at LMC14 in Saclay, France. Radiocarbon 49(2):2919

de Beaulieu J-L, Pons A, Reille M. 1988. Histoire de la 


\section{Hatté et al.}

flore et de la végétation du Massif Central (France) depuis la fin de la dernière glaciation. Cahiers de Micropaléontologie 3:5-36.

Disnar JR, Stefanova M, Bréhéret JG, Macaire JJ. 2011 Microbial mat development and dolomite formation under pre-evaporitic conditions during the Atlantic in a temperate area: the Sarliève Lake (French Massif Central). Organic Geochemistry 42(9):1089-98.

Eglinton TI, Benitez-Nelson BC, Pearson A, McNichol AP, Bauer JE, Druffel ERM. 1997. Variability in radiocarbon ages of individual organic compounds from marine sediments. Science 277(5327):796-9.

Fontana SL. 2005. Holocene vegetation history and palaeoenvironmental conditions on the temperate Atlantic coast of Argentina, as inferred from multi-proxy lacustrine records. Journal of Paleolimnology 34(4): 445-69.

Fourmont A. 2005. Quantification de l'érosion et de la sédimentation dans le bassin de Sarliève (Massif Central, France) au Tardiglaciaire et à l'Holocène. Impact des facteurs naturels et anthropiques [PhD thesis]. Université François-Rabelais de Tours. 419 p.

Fourmont A, Macaire JJ, Bréhéret JG. 2009. Contrasted Late Glacial and Holocene hydrology of Sarliève paleolake (France) from sediment geometry and detrital versus biochemical composition. Journal of Paleolimnology 41(3):471-90.

Fournier G. 1996. Sarliève: un lac au moyen-âge. Association du Site de Gergovie 11:2-34.

Geyh MA, Schotterer U, Grosjean M. 1998. Temporal changes of the ${ }^{14} \mathrm{C}$ reservoir effect in lakes. Radiocarbon 40(2):921-31.

Geyh MA, Grosjean M, Núñez L, Schotterer U. 1999. Radiocarbon reservoir effect and the timing of the Late-Glacial/Early Holocene humid phase in the Atacama desert (northern Chile). Quaternary Research 52(2):143-53.

Hatté C, Jull AJT. 2007. Radiocarbon dating: plant macrofossils. In: Elias SA, editor. Encyclopedia of Quaternary Science. Amsterdam: Elsevier. p 2958-65.

Hutchinson GE. 1975. A Treatise on Limnology. Volume 3, Limnological Botany. New York: John Wiley \& Sons. 660 p.

Kantrud HA. 1991. Wigeongrass (Ruppia maritima L.): a literature review. Washington, DC: US Fish and Wildlife Service. 58 p.

Kessler J, Chambraud A. 1986. La météo de la France. Tous les climats localité par localité. Paris: J.C. Lattès. $312 \mathrm{p}$.

Macaire JJ, Fourmont A, Argant J, Bréheret JG, Hinschberger F, Trément F. 2010. Quantitative analysis of climate versus human impact on sediment yield since the
Lateglacial: the Sarliève palaeolake catchment (France). The Holocene 20(4):497-516.

MacDonald GM, Beukens RP, Kieser WE. 1991. Radiocarbon dating of limnic sediments: a comparative analysis and discussion. Ecology 72(3):1150-5.

Madsen TV, Sand-Jensen K. 1991. Photosynthetic carbon assimilation in aquatic macrophytes. Aquatic Botany 41(1-3):5-40.

Mook WG, van der Plicht J. 1999. Reporting ${ }^{14} \mathrm{C}$ activities and concentrations. Radiocarbon 41(3):227-39.

Murphy LR, Kinsey ST, Durako MJ. 2003. Physiological effects of short-term salinity changes on Ruppia maritima. Aquatic Botany 75(4):293-309.

Raven JA. 1970. Exogenous inorganic carbon sources in plant photosynthesis. Biological Reviews 45:167-221.

Reimer PJ, Baillie MGL, Bard E, Bayliss A, Beck JW, Blackwell PG, Bronk Ramsey C, Buck CE, Burr GS, Edwards RL, Friedrich M, Grootes PM, Guilderson TP, Hajdas I, Heaton T, Hogg AG, Hughen KA, Kaiser KF, Kromer B, McCormac FG, Manning SW, Reimer RW, Richards DA, Southon JR, Talamo S, Turney CSM, van der Plicht J, Weyhenmeyer CE. 2009. IntCal09 and Marine09 radiocarbon age calibration curves, 0-50,000 years cal BP. Radiocarbon 51(4): 1111-50.

Smith FA. 1968. Rates of photosynthesis in characean cells. II. Photosynthetic ${ }^{14} \mathrm{CO}_{2}$ fixation and ${ }^{14} \mathrm{C}$-bicarbonate uptake by characean cells. Journal of Experimental Botany 19(1):207-17.

Soulié-Märsche I. 2002. Les charophytes comme biomarqueurs pour la reconstitution des paléoenvironnements lacustres. In: Miskovsky JC, editor. Géologie de la Préhistoire. Paris: Geopre. p 751-69.

Steeman Nielsen E. 1947. Photosynthesis of aquatic plants with special reference to the carbon sources. Dansk Botanisk Arkiv Udgivet af Dansk Botanisk Forening 8:3-71.

Trément F, Argant J, Bréhéret JG, Cabanis M, Dousteyssier B, Fourmont A, Fournier G, Liabeuf R, Loison G, López Sáez JA, Macaire JJ, Marinval P, MennessierJouannet C, Milcent PY, Prat B, Rialland Y, Vernet G. 2007. Un ancien lac au pied de l'oppidum de Gergovie (Puy-de-Dôme). Interactions sociétés-milieux dans le bassin de Sarliève à l'Holocène. Gallia 64:289-351.

Verhoeven JTA. 1979. The ecology of Ruppia-dominated communities in western Europe. I. Distribution of Ruppia representatives in relation to their autecology. Aquatic Botany 6:197-267.

Yansa C, Long D. 2007. Improving the accuracy of radiocarbon chronologies from lake-sediment cores: testing for the ${ }^{14} \mathrm{C}$ reservoir effect in aquatic macrophytes. Report of findings. CWS Venture Grant Awarded. 9 p. 